corresponds with the physiologically observed through-conducting system. The ectodermal muscle sheets and associated nerve nets, which are well developed in the individual polyps, apparently have no connexions between polyps ${ }^{3}$. I'his agrees with the sharp localization of the feeding responses of individual polyps, which can be referred mainly to the ectodermal musculature. When a very small electrode, carrying condenser shocks at 5/sec., is brought up to a polyp disk or tentacle, a feeding reaction or a slow retraction can be elicited from this one polyp alone; but if the through-conducting system is excited, then distant polyps retract no less than neighbouring ones.

Gatty Marine Laboratory,

St. Andrews. Aug. 10.

${ }^{1}$ Milne-Edwards, H., Ann. Sci. Nat. (2), 4, 321 (1835).

' Hickson, S. J., Quart. J. Micr. Sci., 37, 343 (1895).

${ }^{3}$ Kassianov, N., Z. wiss. Zool., 90, 478 (1908).

"Kukenthal, W., "Handbuch der Zoologie", 1, 697 (1923).

"Hyman, L. H., "The Invertebrates", 1, 547 (1940).

'Horridge, G. A., J. Exp. Biol. (in the press).

'Horridge, G. A., Phil. Trans., B. (in the press).

${ }^{8}$ Horridge, G. A., Proc. Zool. Soc. Lond. (in the press).

\title{
Arterio-Venous Anastomoses in the Teat of a Cow
}

RECENT studies of the circulation in the skin of cattle have shown that arterio-venous anastomoses occur in the ear of the calf and also in the skin of the forehead and cheek ${ }^{1,2}$ but not in the skin of the general body surface ${ }^{2}$. Since they might possibly occur in the skin of other extremities the following investigation was carried out.

At autopsy the tip of a teat of an Ayrshire cow and pieces of skin from the end of the tail and from immediately above the hoof of an Ayrshire calf were obtained. They were fixed in 5 per cent formolsaline and embedded in paraffin. Serial sections of the blocks were cut and stained by Masson's trichrome mathod.

On examination of the sections no arterio-venous anastomoses were found in the skin of the tail and the leg. They were present, however, in the teat, where they could be recognized by the epithelioid cells in their media. In the serial sections it was possible to trace their course from artery to vein. All were apparently in the contracted state. Their outer diameters ranged from 60 to $150 \mu$. Some were short and unbranched while others were tortuous and branched. A typical arterio-venous anastomosis is shown in Fig. I. It has been sectioned at a bend in its course, as can be seen from the shape of its lumen.

The presence of arterio-venous anastomoses in the teats of any species has not been previously reported. It is possible ${ }^{3,4}$ that they may help to control local temperature in conditions of extreme heat and cold. However, they may also be associated with the mechanism of erection of the teat. Although it has been found ${ }^{5}$ that the most essential factor in the erection of the human nipple is the contraction of the smooth muscle core, yet some vascular engorgement of the small sinus-like vessels in the dermal papillæ may also occur. Similar sinus-like vessels occur in the dermal papillæ of the cow's teat. It seems possible that the arterio-venous anastomoses may control the flow of blood through these sinuses just as the arterio-venous anastomoses in the tongue

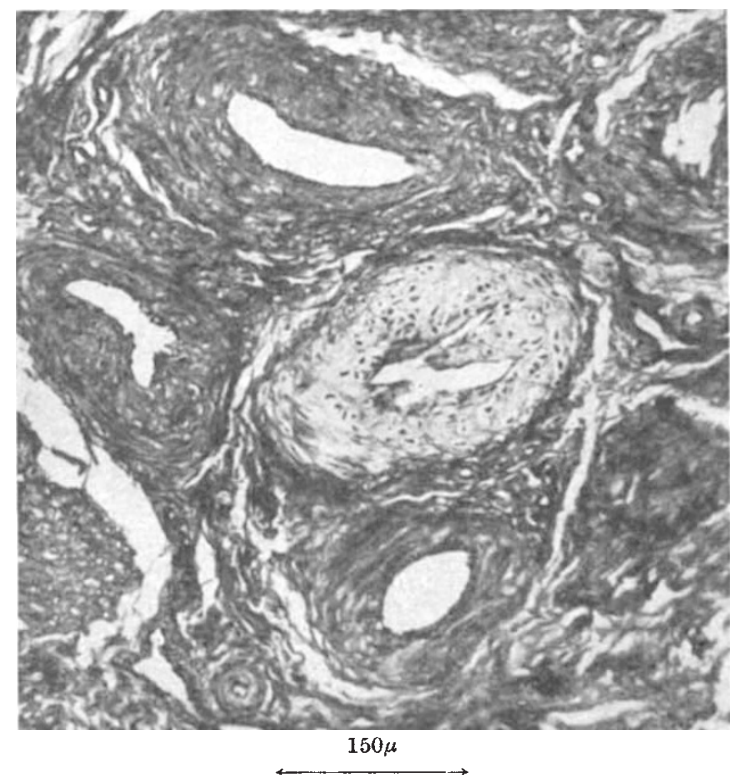

Fig. 1. An arterio-venous anastomosis cut obliquely at a wall. Beneath it lies. Note the epithelioid cells in its thick it and to the left lie the veins into which it drains

of the dog, the sheep and the goat may control the flow of blood through the capillaries of the papillæ ${ }^{6}$.

It is proposed to examine the human nipple and the teats of other animals to find if the occurrence of arterio-venous anastomoses in this location is common in mammalia. Examination of latex casts of the blood vessels of the teat may indicate whether the arterio-venous anastomoses control the blood supply to the sinus-like vessels in the dermal papillæ.

Hannah Dairy Research Institute, A. MyFanwy Nisbet Kirkhill, Ayr. Oct. 12.

${ }^{1}$ Findlay, J. D., and Goodall, A. M., J. Physiol., 121, $46 P$ (1953).

2 Goodall, A. M., J. Anat., 89, 100 (1955).

${ }^{s}$ Grant, R. T., Heart, 15, 281 (1930).

${ }^{4}$ Clark, E. R., and Clark, E. L., Amer. J. Anat., 54, 229 (1934). "Cathcart, E. P., Gairns, F. W., and Garven, H. S. D., Trans. Roy.

${ }^{6}$ Prichard, M. M. L., and Daniel, P. M., J. Anat., 87, 66 (1953).

? Prichard, M. M. L., and Daniel, P. M., Amer. J. Anat., 95, 203 (1954).

\section{Root Dissection: a Method of studying the Distribution of Active Mycelia within Root Tissue}

THE presence of saprophytic micro-fungi in the decomposing cortex of roots of rye-grass ${ }^{1}$ has been studied by a simple modification of a technique, described by Harley and Waid ${ }^{2}$, which was developed to study the active mycelia of root surfaces. Roots at various stages of decomposition, characterized by the colour and condition of the cortex, were selected from rye-grass (Lolium perenne L.) growing under field conditions. The roots were washed by agitation in ten changes of $10 \mathrm{ml}$. of sterile water, and were then cut into 2 -mm. fragments from which the outer cortex was dissected, leaving the central cylinder comprising the inner cortex and stele. Dissection was carried out in dishes of sterile water using sterile forceps and scalpel; with practice this could be done by eye. The $2-\mathrm{mm}$. fragments of outer and inner 